\title{
Brain atrophy after cortical hyperintensities in systemic lupus erythematosus
}

Atrofia cerebral após hiperintensidades corticais no lúpus eritematoso sistêmico

Igor A. Franco, Livia A. Dutra, Hugo A. C. Resende, Fabio Toso, Orlando G. Povoas Barsottini

A 29-year-old woman with systemic lupus erythematosus (SLE) developed seizures, renal failure and coma. Neurological examination was unremarkable; eletroencephalogram and spinal fluid analysis were normal, anti-DNA antibodies were positive. Brain MRI disclosed cortical hyperintensities (Figure). She received metylprednisolone and cyclophosphamide with no improvement, but recovered consciousness after plasmapheresis.
She evolved with psychosis, cognitive complaints and follow-up MRI disclosed brain atrophy. Positive anti-DNA antibody, plasmapheresis response and selective grey matter involvement suggest that cortical hyperintensities were secondary to an immune response against neuronal components rather than postseizures changes or vasculitis ${ }^{1}$. Neurodegeneration may ensue after cortical hyperintensities in SLE.
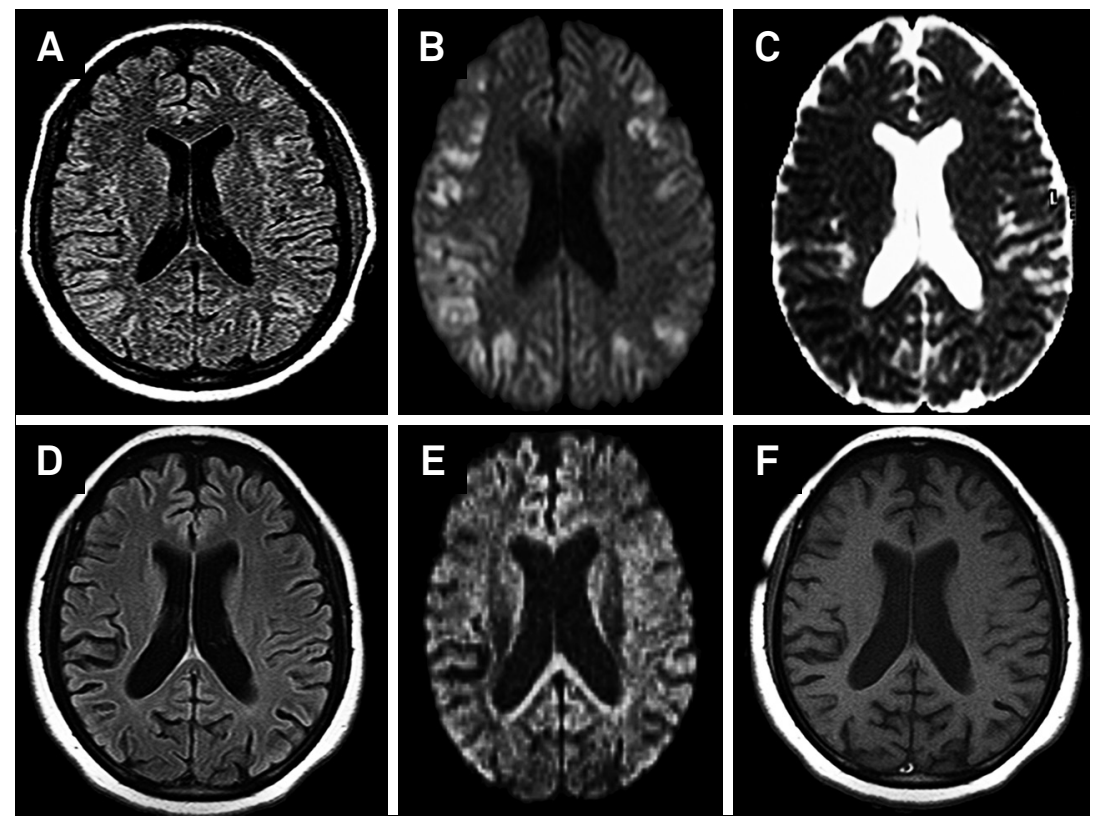

Figure. Initial MRI: A, B and C. Axial FLAIR images showing cortical hyperintensities (A) with increased signal on DWI (B) and decreased signal on ADC map (C), suggestive of cytotoxic edema. Follow up MRI six months later: D, E, F. Axial FLAIR (D) and DWI (E) images showing improvement of signal abnormalities. A non-contrast axial T1 image (E) showing brain atrophy.

1. LuyendijkJ, Steens SC, Ouwendijk WJ, Steup-Beekman GM, Bollen

EL, Grond J et al. Neuropsychiatric systemic lupus erythematosus: lessons learned from magnetic resonance imaging. Arthritis Rheum. 2011;63(3):722-32. doi:10.1002/art.30157

Universidade Federal de São Paulo, Departamento de Neurologia e Neurocirurgia, Divisão Geral de Neurologia, Sao Paulo SP, Brazil. Correspondence: Igor de Assis Franco; Rua Pedro de Toledo, 650;04039-030 São Paulo SP, Brasil; E-mail: igorafranco1@gmail.com Conflict of interest: There is no conflict of interest to declare.

Received 13 March 2015; Received in final form 06 July 2015; Accepted 30 July 2015. 